\section{Recurrence of Hyperthyroidism Shortly after Return of Normal Suppressibility by Triiodothyronine}

British Medical Fournal, 1970, 3, 327

Absence of suppressibility of thyroid function by exogenous thyroid hormone is typical of hyperthyroidism (Werner and Spooner, 1955). It is generally accepted that restoration of normal suppressibility by triiodothyronine $\left(T_{3}\right)$ is a reliable indicator of a lasting remission in Graves's disease (Cassidy, 1965; Alexander et al., 1966). In fact, some workers stop treatment with thyrostatic drugs if the $T_{3}$ test is normal (Alexander et al., 1966). We are therefore prompted to report a recurrence of hyperthyroidism within four weeks after finding normal suppressibility of thyroid function by $T_{3}$.

\section{Case Report}

A woman aged 32 was first seen in December 1966 with a oneyear history of classical symptoms of hyperthyroidism. On physical examination typical thyrotoxic signs were found. The thyroid gland was diffusely enlarged to about twice normal size. Over the gland a systolic-diastolic murmur was heard. Eye symptoms were absent. Protein-bound iodine (P.B.I.) was 9.1 $\mu$ g./100 ml. B.M.R. + $75 \%$. She was treated successfully with methimazole for 16 months. Medication was stopped in April 1968. At that time the thyroid gland was barely palpable.

In December 1968 P.B.I. was $4.6 \mu \mathrm{g} . / 100 \mathrm{ml}$. and ${ }^{131} \mathrm{I}$ uptake $22 \%$ after 3 hours and $46 \%$ after 24 hours. Following $T_{3} 75$

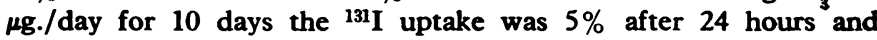
P.B.I. $5.7 \mu$ g. $/ 100 \mathrm{ml}$. Four weeks after evidence of suppressed thyroid function signs and symptoms of hyperthyroidism had recurred. The size of the thyroid gland was not increased, but the P.B.I. had risen to $10.2 \mu \mathrm{g} . / 100 \mathrm{ml}$. Two weeks later, while the patient was still toxic, ${ }^{131}$ I uptake was only $13 \%$ after 3 hours and $18 \%$ after 24 hours. P.B.I. at that time was $7.7 \mu \mathrm{g} . / 100 \mathrm{ml}$. A scintigram showed a diffuse distribution of radioactivity in a normal-sized gland. No treatment was given.

In June 1969 the patient was still toxic, and thyroid studies were repeated. P.B.I. was $8.9 \mu \mathrm{g} . / 100 \mathrm{ml}$. and ${ }^{131} \mathrm{I}$ uptake $67 \%$ at 24 hours. After $T_{3} 75 \mu \mathrm{g}$./day for 10 days the ${ }^{131} \mathrm{I}$ uptake was $70 \%$ in 24 hours. The diagnosis of recurring Graves's disease was made and the patient was treated with $2 \mathrm{mCi}$ of ${ }^{131} \mathrm{I}$ and methimazole. Data of the thyroid studies are shown in the Table.

\section{COMMENT}

In this case the normal suppressibility of thyroid function in December 1968 was in accordance with the clinically euthyroid state during a period of nine months after stopping antithyroid drug treatment. Remarkably, four weeks after the administration of $T_{3}$ for 10 days hyperthyroidism had recurred according to symptoms, signs and P.B.I. level, though the ${ }^{131}$ I uptake was not increased. On repeated interrogation the
Thyroid Function Tests and Clinical Signs at Various Dates in Reported Case

\begin{tabular}{l|c|c|c|c|c|c|c}
\hline & \multicolumn{3}{|c|}{1968} & \multicolumn{4}{c}{1969} \\
\cline { 2 - 7 } & $\begin{array}{c}2 \\
\text { Dec. }\end{array}$ & $\begin{array}{c}4 \\
\text { Dec. }\end{array}$ & $\begin{array}{c}17 \\
\text { Dec.* }\end{array}$ & $\begin{array}{c}21 \\
\text { Jan. }\end{array}$ & $\begin{array}{c}11 \\
\text { Feb. }\end{array}$ & $\begin{array}{c}4 \\
\text { June }\end{array}$ & $\begin{array}{c}15 \\
\text { June* }\end{array}$ \\
\hline Thyroid 131I uptake at 3 hours \\
(\%)
\end{tabular}

* After $T_{3}$.

patient, her pharmacist, and house-physician denied any iodine or other drug treatment. Four months later the diagnosis of recurrence of Graves's disease was definite and she was again unresponsive to $T_{3}$.

It is tempting to speculate that recurrence of hyperthyroidism in this patient was initiated by excessive thyroid stimulating hormone (T.S.H.) stimulation resulting from previous suppression by $\mathrm{T}_{3}$. The lowered ${ }^{131} \mathrm{I}$ uptake in February 1969 might then be explained by resuppression of T.S.H. by the excess of endogenous thyroid hormone secreted earlier and still partially circulating according to the slightly raised P.B.I. Finally, in June 1969 Graves's disease recurred. It is thought that the hyperthyroid state found four weeks after the $T_{3}$ test in December 1968, and possibly resulting from T.S.H. stimulation, had triggered the unknown (antigenic?) stimulus leading to Graves's disease, perhaps by long-acting thyroid stimulator formation. In Graves's disease the serum T.S.H. level is lowered (Adams et al., 1969). The possibility, however, cannot be ruled out that emotional factors, often said to initiate Graves's disease (Alexander et al., 1968), act in a comparable way, as suggested in this patient, by temporary T.S.H. overproduction, triggering in genetically predisposed per ons the unknown process underlying Graves's disease.

In conclusion, the observations made in this case show that normally suppressible thyroid function after treatment for Graves's disease does not guarantee a lasting remission.

J. A. WILS, M.D.

P. W. C. KLOPPENBORG, M.D.

Department of Medicine, Division of Endocrinology, University Hospital St. Radboud, Nijmegen, The Netherlands.

REFERENCES

Adams, D. D., Kennedy, T. H., and Purves, H. D. (1969). Youmal of Clinical Endocrinology and Metabolism, 29, 900.

Alexander, W. D., Harden, R. McG., and Shimmins, J. (1966). Lancet, 2,1041 .

Alexander, W. D., Harden, R. McG., and Shimmins, J. (1968). Lancet, 2, 196.

Cassidy, C. E. (1965). Journal of Clinical Endocrinology and Metabolism, 25, 155

Werner, S. C., and Spooner, M. (1955). Bulletin of the New York Academy of Medicine, 31, 137. 